\title{
Sustainability, thoroughbred racing and the need for change
}

\author{
Iris Bergmann \\ School of Geosciences, University of Sydney, Australia
}

\begin{abstract}
Summary: Globally, the thoroughbred breeding and racing industry is reporting a declining trend. A report commissioned by the Jockey Club in the US, known as the McKinsey report, explicitly linked the public's concern with animal welfare and the use of drugs to declining betting and attendance in the US. In various racing nations in Europe, in Australia and the US, thoroughbred racing is experiencing pressures from external sources and from within, with even industry participants calling for change. The industry is concerned with the integrity of racing. Structural changes, regulation and transparency in reporting are all issues identified in need of improvement in some racing nations. These are important issues and potentially contribute to better welfare outcomes. However, they do not address the principal question emerging from evolving social norms and values of whether thoroughbred racing is ethically justifiable, and if so, how it can be conducted so that it is socially acceptable. To address the declining trend, the McKinsey report framed the suggested strategies around the concept of sustainable growth and thus adopted the rhetoric of sustainable development. The research in this paper takes up the theme of sustainability and applies it to the thoroughbred industry. Elsewhere it has been shown that a focus on growth, as in the sustainable development model, is at the root of unsustainability. Therefore, it is argued in this research that an ecologically oriented sustainability framework is better suited to fully address the ethical and welfare issues in the industry. In this study, it is assumed that society, for the time being, accepts thoroughbred breeding and racing. Under this assumption, the concept of ecological sustainability is applied as a methodological tool by using it as a language system to investigate ethical and welfare issues in the thoroughbred industry. The following recommendations emerge from this research: There is the need for the industry to engage with issues of normativity and to develop alternative models of what constitutes success beyond winning a race. There is also need to advance knowledge production to better understand and respect the experience of thoroughbreds and thoroughbred knowledge systems, determinants of how to remain within the natural physical and emotional limits of the horse, the limits of human uses of horses, and how to promote the flourishing of horse and human-horse relationships in this industry. Engagement with these matters can better address issues of (un)sustainability and move the industry from an economically driven business and management model to a welfare driven model. The discussion of what constitutes a sustainable horseracing industry is inevitable. The question of the continuation of the use of thoroughbreds requires social negotiations in the interest of social sustainability. This is an ongoing dialogue as society's ethics and values evolve. It would appear that the thoroughbred industry can expect to greatly benefit from proactively engaging with this process.
\end{abstract}

Keywords: Animal welfare / equine welfare / sustainability / sustainable development / systems thinking / thoroughbred racing / thoroughbred industry / naturalness / animal autonomy

Citation: Bergmann I. (2015) Sustainability, thoroughbred racing and the need for change. Pferdeheilkunde 31, 490-498

Correspondence: Dr. Iris M. Bergmann, School of Geosciences, The University of Sydney, Sydney NSW 2006, Australia, E-mail: iris.bergmann@sydney.edy.au

\section{Introduction}

Recently, the Jockey Club in the US commissioned a study into the factors that influence the economics of thoroughbred racing. The resulting report "Driving Sustainable Growth for Thoroughbred Racing and Breeding" (Singer and Lamb 2011) came to be known as the McKinsey Report. In this report, Singer and Lamb (2011) confirm what industry participants have been grappling with for some time: demand for thoroughbred racing is down, supply has contracted, and the core fan base is shrinking. The projected economics of thoroughbred racing in the US all indicate an industry in decline.

This general decline is echoed in other important racing nations, including Australia (Australian Racing Board 2014), Ireland (Kavanagh 2013), the UK (Gribben 2015), Japan (Goto 2013) and Germany (Direktorium für Vollblutzucht und Rennen 2013). While there are a few nations demonstrating an upward trend (Kavanagh 2013), globally, the trend is downward (IFHA 2014). In Germany, Andreas Tiedtke, then executive of the leading German body Direktorium für Voll- blutzucht und Rennen (2013) pointed out the need for structural changes in the German thoroughbred industry. He hoped that the number of foals of under 900 in 2012 was at an all-time low. However, the numbers dropped below 800 in 2013 (IFHA 2014).

Singer and Lamb (2011) identify five major causes for the decline in the US, of which a decline in brand perception is of particular interest here. Singer and Lamb (2011) report that thoroughbred racing suffers a strong negative public perception. They state that despite recent safety initiatives such as the establishment of the Equine Injury Database in 2008, only $22 \%$ of the general public have a positive impression of thoroughbred racing. Only $46 \%$ of current fans - a fan being someone who attends an event three or more times per year - would recommend that their friends follow thoroughbred racing. $78 \%$ of fans would stop betting if they knew horses were not treated well. Importantly, Singer and Lamb (2011) find that animal welfare, in particular horse welfare, is a growing concern for the US public, and concerns over animal 
safety and welfare and medication are consistent themes in consumer and stakeholder research.

The relevance of the report is twofold. First, in focusing on the concept of "sustainable growth", Singer and Lamb (2011) and the Jockey Club have adopted the rhetoric of "sustainable development". Second, the report explicitly links the public's concern with animal welfare and doping to declining betting and attendance. Similar links between sustainable development and animal welfare have already emerged in the animal agriculture sector. For example, in the US, a group of scientists suggests that the dairy industry suffers a growing loss in confidence, so much so that its long-term sustainability is at risk. This is not only because of its environmental and climate change impact, but because it does not meet public expectations of how farm animals ought to be treated (e.g. von Keyserlingk et al. 2013, 5405). Von Keyserlingk et al. (2013) urge the industry to consider animal welfare as a sustainability concern under the sphere of social sustainability. Social sustainability thus refers to the social acceptability of how animals are treated. Animal welfare is present as a component of sustainable agriculture and social sustainability in policy discussions at governmental levels in Europe (e.g. Buller and Morris 2008, see for example also EurSAFE 2012, Humane Society International et al. 2013).

Arthur (2011) states that "for years, horse racing swept the dark side of racing out of the public eye". This is now no longer possible. There is mounting pressure from external sources demanding change within the industry, including from animal protection organizations, the general public, and through public exposure by the media. Many comment on the impact of new technology that makes it possible to quickly bring to public attention what is happening on and off the race track. For example, Montoya et al. (2012) argue:

"The communication of images, unfiltered commentary, blogging, and other activities has an increasingly important role in both education about the reality of horse racing and the shaping of ethics and values in response to that reality. With powerful, distressing images and strongly critical commentary based on animal rights and welfare arguments, the impact of antijumps campaigns is now far-reaching."

In particular, jumps racing "is viewed variously as exciting, archaic and barbaric" (McManus et al. 2014). Jumps racing has been banned in NSW, Australia, on animal welfare grounds (Montoya et al. 2012). What we can see unfolding in jumps racing may be a "sign of things to come" (McManus et al. 2013) for thoroughbred racing in general and globally. As McManus et al. (2013) conclude, "greater ethical scrutiny will be applied to the thoroughbred industry whether it likes it or not".

Arguably, it is the issue of drugs that is taking thoroughbred racing to a tipping point across the continents. High profile doping cases in recent years generated much publicity and scrutiny leading to a questioning of the future of the industry (PETA 2013, Ross 2014, Bartley 2015). There is also mounting pressure from within the industry. Some industry participants identified the need for structural changes, and the need to address issues of transparency and regulation. In Australia, for example, Anderson (2014) states that "good racing pak- kage" is based on transparency comprising easily accessible information of the horse's history. He also points to the structural complexity and disunity of racing in Australia hindering a national approach (Anderson 2015). In the US, an alliance of breeders and owners joined by veterinarians and other individuals, the Water Hay Oats Alliance (WHOA 2014), has been formed led by the "industry titan" breeder Alfred Hancock (Miller 2014). According to Miller (2014), Hancock credits the momentum for reform to the McKinsey report. WHOA has entered a coalition with the Jockey Club, an animal welfare organization (the Humane Society of the United States) and others to advance drug regulation at the federal level (Coalition for Horse Racing Integrity 2015). The coalition cooperates with the non-governmental US Anti-Doping Agency (USADA) who is signatory to the World Anti-Doping Code (WADA) and WADA international standards. As Miller (2014) suggests, the protection of thoroughbreds is no longer considered a part of an extremist agenda.

\section{The theoretical framework}

The author takes up the theme of sustainability and applies it to the thoroughbred industry. In doing so, two approaches are used. First the author follows Barker et al. (2014b) who suggest that sustainability does not lend itself to be conceptualized as an end goal or as an organizing concept. Instead, the utility of sustainability is based in it "providing a language system" (Barker et al. 2014b). Second, the sustainability langvage used here is based on an ecological orientation to respond to the underlying causes of unsustainability as explained below. Sustainability has evolved since the 1950s based on concerns of, amongst others, environmental degradation, loss of biodiversity and habitat, natural resource depletion, and concerns about the pursuit of endless economic growth (Kidd 1992, Washington 2015). Many different conceptions of sustainability have emerged since. The most well-known approach is the sustainable development model. This model has been popularized by the World Commission on Environment and Development through their report which came to be known as the Brundtland Report (WCED 1987).

One way the Brundtland Commission defined sustainable development is "development that meets the needs of the present without compromising the ability of future generations to meet their own needs" (WCED 1987). This definition serves as reference point at governmental and intergovernmental levels, and in the private sector. It refers to the important dimension of intergenerational equity and much work has been done since to advance this idea. However, other definitions concerning the ethical, social and ecological spheres raised in the report have been ignored (MacNeill 2006). Many have criticized the Brundtland report for its focus on the idea of (sustainable) growth, but many others in government and business have adopted sustainable growth as their dogma.

However, the call for a focus on ecological sustainability is becoming ever more urgent due to the mounting evidence of the anthropogenic impact on this planet (Steffen et al. 2004, 2011 , Rockström et al. 2009). It is becoming increasingly evident that the ability of future generations to meet their needs is being compromised, and in some places, this is already the case for present generations. The insistence on 
endless economic growth, aka sustainable growth, is at the root of unsustainability. As Sterman states: "The question is not if growth will cease, but when and how... Many believe that the goal of environmental policy is to enable "sustainable growth", an impossibility. Material growth in a finite world must eventually cease; by definition it cannot be sustained" (Sterman 2012).

This realization has consequences for the ambition of the Jokkey Club and other industry bodies whose focus is on growth. To better understand the link between sustainability, and the dependence of humankind and the economy on nature, Costanza et al. (2013) suggest the following model: The economy needs to be seen as situated within society which is situated within nature, rather than nature being situated within human society within the economy. The thoroughbred industry represents a micro-cosmos of the larger economy. Thus, we can adopt Costanza et al.'s model and replace "nature" with "the thoroughbred" to demonstrate the dependence of the industry on the well-being and functional integrity of the horse.

An ecological orientation of sustainability can take account of the need to protect the thoroughbred, as it takes account of the need to protect nature, both in its own right and for human survival (for example Washington 2015). The ecological sustainability orientation assumes that all life, biotic and abiotic nature, has intrinsic, mind-independent value. It accepts that humankind depends on the functioning of natural systems for survival. It is critical of the instrumentalization of nature and natural processes. It also accepts that there are biogeophysical limits on this planet. This means that there are limits to human consumption, and any use of the planet's resources needs to remain within these limits without compromising natural processes and other life forms.

The ecological orientation of the sustainability framework implies that the interests of nonhuman species are not subordinate to the interests of humans per se. It centers the interest of thoroughbreds and their physical and emotional integrity. The underpinnings of the notion of ecological sustainability also lead to adopting a systems perspective, seeing humans, nonhumans and the natural world as part of a larger interconnected community. In the case of thoroughbreds, this means that they are part of a complex socio-ecological system and the integrity of the system depends on the emotional and physical integrity and well-being of the thoroughbred.

\section{An overview of some of the ethical and welfare issue in thoroughbred racing}

Before giving a brief overview of some of the ethical and welfare issue in thoroughbred racing, the author acknowledges that, as McManus et al. (2013) remind us, the human-horse relationship is "complex and multi-dimensional" and she acknowledges that many industry participants want and do the best for their horses. There are differences in regulation and statistical data between racing jurisdictions and racing nations and this cannot be considered in great detail within the scope of this discussion. However, from the evidence available there is an underlying consistent logic within the global thoroughbred industry that points to the need for a new approach to addressing welfare and ethical issues. The author also acknowledges that there are human costs associated with thoroughbred racing (e.g. Hitchens et al. 2009, Warrington et al. 2009, Castañeda et al. 2010, Bogdanich et al. 2012, Benns 2013, Duffy 2013). The human impact is an important aspect of the sustainability of thoroughbred racing but its closer examination is beyond the scope of this paper.

As Arthur (2011) states, horseracing presents a minefield for thoroughbreds. The ethical and welfare issues contrast highly visible ones such as doping (e.g. Keogh 2014) with invisible ones where statistics and other details are neither publicized nor collected. McManus et al. (2013) have synthesized surveys, interviews with industry participants, and other information to compile an overview of the ethical and welfare issues inherent in the thoroughbred industry. These concern the entire lifecycle of the thoroughbred, beginning with the process of breeding, through to transport and housing, feeding, training, racing, auctions and sales, and the exit from the industry.

They refer to the manipulation of the mare's fertility with powerful drugs and artificial lighting in the winter months, the global transport of breeding stallions with the inherent risks in long distance travel, and the foal that arrives potentially with conformational and soundness issues. They found that breeding is often based on speed not on soundness. This increases the need for further intervention to address anatomical deficiencies and faults (McManus et al. 2013). McManus et al. (2013) refer to this as a "vicious cycle of conformational fault building, earlier racing and retirement, rapid breeding and veterinary correction".

When racing, thoroughbreds compete near their physical limits, there is "little margin of error" in racing at full speed and structural failures of bones and ligaments frequently are catastrophic for horse and rider (Arthur 2011). Catastrophic limb injury is the most common reason for thoroughbred fatality on the racetrack (Boden et al. 2006). However, thousands of thoroughbreds are injured or die each year before they even race. In the majority of cases, such as in Australia, official records are not collected. In a New York Times investigation it is reported that in the US, 29 horses die each week on the racetrack (Bogdanich et al. 2012). During an undercover investigation into the US thoroughbred racing industry, assistant trainer Scott Blasi has been filmed exclaiming: "You cannot believe how many they hurt and kill before they even get to the race track. It's mindboggling" (PETA 2014).

In Australia, the Coalition for the Protection of Racehorses (CPR) (2014) explains that many of those who are registered to race may not have the ability or temperament for racing, they are too slow or suffer early injuries. Thousands of thoroughbreds born and raised will thus be of no value for breeding and racing, and "with no earning potential, they face an uncertain future" (CPR 2014). CPR suggests the number of thoroughbreds slaughtered in Australia each year is in the "high five figures" (Ward Young 2013). Peter McGauran, CEO of the Australian Racing Board, counters that the numbers are at "an estimated 8000" but he admits that the fate of racehorses exiting the industry is "still an unresolved issue" (McGauran 2013). The situation in Australia is not unique. Drugs in the thoroughbred industry are some of the biggest 
issues that intersect with welfare throughout the life of the thoroughbred. There are questions in relation to drugs and medication, legal or illegal applications, therapeutic uses to help horses recover in times of illness, or "bulk them up" to make them look attractive to the potential buyer (McManus et al. 2013). McManus et al. (2013) also found that there appears to be overuse of pharmaceutical intervention to prepare young horses for sale and racing. They found that many young horses suffer from stress injuries and are treated routinely with anti-inflammatory drugs to mask pain and speed up recovery (McManus et al. 2013). They also refer to "appearance enhancement" through medication and surgery. In mature horses, painkillers, sedatives and enhancers are commonplace. Masking injury rather than treating it and giving it time to heal for full recovery, often leads to major injury or death (McManus et al. 2013). In all, the racing industry projects an image that can be summarized with the words of racing commentator Horn (2014): "They throw enough eggs at the wall and hope the occasional one doesn't break."

Finally, as McManus et al. (2013) found, "the end stage of a racing horse's life is often one of the worst ethical failures manifest in the whole industry", with many ending up in abattoirs, often after long transports, to be killed.

\section{Discussion and ways forward}

The thoroughbred industry has operated and is operating with little uniform and independent regulation and oversight, and a lack of transparency. Most insight into welfare and ethical issues in the industry has had to rely to a large part on the work of not-for-profit animal protection organizations, by undertaking their own data collection, or by interpreting data published by the industry. Animal welfare advocates have identified the lack of transparency as a major issue. Arthur (2011) states that "reporting is haphazard, unofficial, reported by interested parties, and generally unverifiable."

Addressing structural issues, transparency and regulation has been identified by industry actors as dimensions requiring urgent attention. There are two examples for regulation in the environmental management field that could be considered for adoption in racing. In the case of doping, Camporesi and Knuckles (2014) suggest to shift the burden of proof. They apply the lessons from environmental sustainability to high-performance sport. In the context of environmental sustainability, it has been proposed to shift "the burden of proof away from regulators in order to alter the practice of discounting the planet's future health for current economic gains" (Camporesi and Knuckles 2014). They explain that the burden of proof for doping should not rest on the athlete or the team of sports doctors but on the sponsors. Penalties would be imposed on the sponsors if doping would be found. They suggest that by making the companies accountable, sponsorship money and a win-at-all-costs mentality in sports that in turn leads to doping could be de-linked, and subsequently there would be no discounting of the future health of the athlete (Camporesi and Knuckles 2014). In another example, Arthur (2011) proposes to put an economic cost on racing injuries arguing that "improving horse safety is easier to accomplish when doing so provides an economic benefit". This is a common approach for climate protection in the form of putting a prize on carbon, and lessons could be learnt form that field.

Improving transparency and regulation is important and can improve welfare outcomes, if transparency and regulation go beyond the aim of protecting the integrity of the race and shift the focus on protecting the horse. However, they do not address the fundamental question of whether thoroughbreds should be bred and raced in the first place and if so, how this can be conducted so that it is socially acceptable. On the basis that thoroughbred breeding, training and racing is accepted by society in principle, then an ecologically oriented sustainability framework offers some insight into the "how". This is discussed in more detail below.

The normative stance, obligations and the spectrum of rights

To begin with, it appears that for the industry to move onto a trajectory of sustainability, a reconsideration of their normative stance is required. Their current normative stance appears at odds with an ecological sustainability framework. As McManus et al. (2013) conclude, for most in the industry and due to the commercial realities, the horse has predominantly instrumental value, and many see horses as commodities, which makes horses "highly vulnerable to unethical treatment". The thoroughbred industry at large appears reluctant to address normative questions inherent in public concerns, or even denies that any such questions exist. Ironically, this in itself is a normative stance. This normative stance says that it is acceptable that horses die and get injured in horseracing and training, on and off the track. "Racing fatalities and injuries were just an accepted part of the cost of doing business" (Arthur 2011 ). There is a cavalier manner displayed by some even in relation to the death of a horse, as jumps racing veteran trainer John $\mathrm{O}^{\prime}$ Connor demonstrates:

"We lose one occasionally, that's a fact and it can't be helped. They lose the occasional horse on the flat... death is just part of the sport... I don't think about it. Because I'm confident that they're competent, they're well trained, they're fit and if an accident happens, so be it" (O'Connor 2014).

The dominant normative stance of the industry also suggests that it is acceptable to use invasive methods to manipulate, control and manage the horse so they are able to cope just enough with the demands placed on them. Horses are made to fit into the system like square pegs in round holes. Use of medication and other practices is fabricated as being required in the interest of animal welfare.

Animal welfare scientist Broom suggests that "we should describe the obligations of the actor rather than the rights of the subject. If we keep or otherwise interact with animals we then have obligations in relation to their welfare" (Broom 2011). This is consistent with the sustainability ethic which includes obligations to nature, however, ecological sustainability adopts in parallel a rights approach often based on ideas of justice. Environmental justice as a normative idea is an important concept in sustainability. It considers the equitable distribution of burdens and benefits to different generations (e.g. Dobson 1998). Ecological justice is an analogue concept 
applied to justice concerns of wild species and ecosystems arguing for their right to flourish (Wuerthner et al. 2014). Buller and Morris (2008) make the case for applying justice to domestic animals in the context of sustainable agriculture and their argument can be extended to thoroughbreds. Under a sustainability framework, one would need to consider such concepts as justice, moral rights, rights to health, dignity and life satisfaction in relation to the thoroughbred.

McManus et al. (2013) suggest the evolution of an ethic of egalitarian care replacing any possible anti-ethic of domination and exploitation, which they call a "whispering ethic". They believe that such an ethic "requires empathetic and caring people who put the intrinsic value of horses above their instrumental value". They propose that within such an ethical space, the co-evolution of horse and human can continue.

Human professional sports have undergone similar ethical crises, such as cycling, and found that doping heavily damaged the public perception of their sport. It seems that the public has a stronger interest in an ethical contest than in the absolute speed of a race. For the public, a race where the participants are not hurt or abused or cheating is still a race worth watching, even if the athletes are not as fast as they would be doped. In human sport, obligations to the welfare of the athlete do not destroy the sport; they enhance the public's interest in the sport. This suggests that the sustainability of thoroughbred racing might benefit from employing a similar normative change toward centering the interests of the thoroughbred.

\section{Mutual flourishing}

Jones et al. (2014b) suggest that sustainability represents "a condition or set of conditions whereby human and natural systems can continue indefinitely in a state of mutual wellbeing, security, and survival". Thus the thoroughbred can be contextualized as being part of nature, but also as being part of an interspecies community with humans. Senge (2014b) considers sustainability as linked to "what constitutes a healthy community in the future". Similarly here, the thoroughbred can be considered as part of an interspecies community, and as one of being part of their community of conspecifics. In either case, sustainability is about the flourishing of both, human and horse, and of the interspecies relationship for mutual benefit. The question is whether this is indeed possible.

The work of Birke and Hockenhull (2015) indicates that there are differences in qualities of relationships between humans and horses during an activity. Based on their observational study, perhaps it can be tentatively concluded that mutual activity can lead to mutual well-being:

"When these working relationships function well, both partners are attentive to each other and to the task in hand, less ready to be distracted by outside influences. There is mutual trust and cooperation, giving an impression of harmony. In that sense, the horse has some agency, and both horse and person work together, even within the obvious physical constraints" (Birke and Hockenhull 2015).

\section{Competitiveness and sustainability}

The highly competitive nature of racing poses challenges to any possibility of mutual flourishing as part of a shared activity. Some conditions in the human context have been identified for sustainability in high performance sport and lessons can be learnt from those. First, there needs to be an acceptance of the natural limits of the body and of the limits based on the psychological make-up of the individual, and a commitment to working with those and not against those (compare Barker et al. 2014b). Second, achieving skill and fitness without injury is a goal that needs to develop as a form of sociocultural learning (Barker et al. 2014a). Third, caring is regarded as an important basis for coaching; caring means to respect the players, value them, involve them, have dialogue with them, listen to them and support them. Finally, it is concluded that competitiveness, dedication and hard work can coexist alongside compassion, empathy, participation and caring (Annerstedt and Lindgren 2014, Schubring and Thiel 2014). In a sustainability approach to horseracing, horseracing would shift from being a commodity to horseracing as community that fosters the flourishing of the horse and the human-horse relationship within their shared activity (compare Barker-Ruchti et al. 2014).

Sport under a sustainability framework considers the dimension of flourishing as a measure of success rather than relying on being the fastest as the only measure, but also on a redesign of the competitive activity (compare Loland 2001, 2006). One task is to define what flourishing means. Some quantifiable information to measure success in those terms could be the number of horses a trainer has that fail to finish a race or do not finish in the official race charts, and in the number of horses dying under a trainer's care (Arthur 2011). It could also include the circumstances under which horses exit the industry, the condition they are in when they exit the industry or move into breeding, what post-racing career could be established, and the longevity of the thoroughbred.

\section{Co-production of knowledge}

Many questions are open as to how thoroughbreds experience their lives and the practices within the industry. Many industry participants claim that thoroughbreds "love" to race and jump (McManus and Montoya 2012). An investigation of thoroughbred experience and an assessment of its consequences is in order. The veterinary sciences would begin to ask different questions than those they have traditionally asked. For example, in the case of exercise-induced pulmonary haemorrhage, the question would not be what kind of medication stops bleeding from the lungs, but rather whether it is justifiable to make the horse perform in a way that leads to bleeding from the lungs? What is the limit to performance so that bleeding does not occur? In what way can breeding, training and racing contribute to the flourishing of the thoroughbred? What are non-invasive methods to support their health and welfare? In cases where there is uncertainty, under a sustainability paradigm, the precautionary principle would prevail.

Our knowledge of animal suffering and the animals' ability to feel joy and life satisfaction, and the changing views on what this means for animal welfare is growing (e.g. Broom 2011). 
The need for more efforts into the empirical investigation of the impact of all aspects of training and keeping of horses has been recognized by Meyer (2015). Meyer (2015) suggests there are differing views over what constitutes the nature of the horse, in particular in terms of the relevancy of innate dispositions of the horse and the relevancy of attitudes acquired by learning. This leads to differing perspectives on what behaviour the horse is able to learn, and on what exceeds the horse's ability to adapt and cope (Meyer 2015).

A concerted effort of interdisciplinary work is required to address the above questions, involving a diverse range of experts for example from the disciplines of ethology, veterinary science, animal ethnography, animal geography, animal and environmental ethics, and horsepeople from within and outside the racing industry. Their work will be part of mapping the knowledge system (Garlick and Austen 2014) of thoroughbreds to better understand what constitutes positive and negative life experiences and what it means for them to flourish.

\section{Conclusion}

For most of its existence, the thoroughbred racing industry has taken the thoroughbreds and the public for granted. This comfortable existence however is now disrupted and cannot be reinstated. The discussion of what constitutes a sustainable horseracing industry is inevitable. It would appear that the question of the continuation of the use of thoroughbreds requires social negotiations in the interest of social sustainability. It can be expected that this will be an ongoing dialogue as society's ethics and values evolve, and as the industry responds to those. Rather than playing catchup, the industry could take a proactive stance.

The thoroughbred industry has recently begun to adopt the rhetoric of sustainable development. This may indicate that a further shift toward adopting a broader range of sustainable development policies is imminent to fall in line with corporate responsibility practices internationally. However, their focus is on sustainable growth alone and it has been shown that a focus on growth is at the very root of unsustainability. Following the preceding integrated discussion of global sustainability concerns and the use of thoroughbreds in racing, we can't help but see parallels between the exploitation of natural resources of this planet and the exploitation of the body and physical ability of the thoroughbred.

To protect thoroughbreds, reform in the industry should go beyond structural measures and measures of regulation and transparency. Although these are important supportive initiatives, they can only in part address the principle concerns about thoroughbred welfare. Based on the evidence it is suggested that the industry engage with issues of noramativity and when alternative models of what constitutes success beyond winning a race. The industry could support the coproduction of knowledge to advance the understanding of the experience of thoroughbreds and thoroughbred knowledge systems, and of determinants of how to remain within individual physical and emotional limits of the horse. The aim should be to foster the flourishing of horse and human-horse relationships in the industry to replace the dominant current model of expoitation and commodification. There is also the need to work with par- ties from outside the industry including animal protection organizations to better understand social expectations of how thoroughbreds ought to be treated in order to advance the social acceptability of the industry. Engagement with these matters can better address issues of (un)sustainability and move the industry from an economically driven business and management model to a welfare driven model. Barry Weisbord (Weisbord 2014), publisher of the Thoroughbred Daily News, puts the need for change most blatantly:

"This isn't the time for a measured response. This isn't the time for model rules. This isn't the time to shoot the messenger, and it's not a time for band aids. This is a time for a radical change of the way we do business. We cannot come at this with a pop bottle rocket. This is the time for shock and awe..."

\section{Acknowledgements}

The author acknowledges the support of a University of Sydney Postgraduate Scholarship funded through the Australian Research Council (ARC DP130104933) in "Caring for Thoroughbreds: Addressing social, economic and welfare issues in international horse racing". The author is indebted to Dr William T. Langford for his ongoing, unflattering and hands-on critique of earlier versions of this paper which greatly helped to focus the argument. She also thanks Professor Phil McManus for his helpful comments on an earlier draft. Last but not least, Dr. Hanspeter Meier deserves a big thank you for sharing his invaluable knowledge of thoroughbreds and welfare issues and for pointing out important sources of information.

\section{References}

Anderson S. (2015) Opinion: If we could start all over. Racing.com. http://www.racing.com/news/2015-04-30/opinion-if-we-couldstart-all-over.

Anderson S. (2014) What is a High Quality Racing Product? Presentation at The Business and Ethics of Racing and the Role of Vet in Racing Seminar, Moonee Valley Racecourse, Melbourne, 8 August Annerstedt C., Lindgren E.-C. (2014) Caring as an important foundation in coaching for social sustainability: a case study of a successful Swedish coach in high-performance sport. Reflect. Pract. 15, 27-39

Arthur R. M. (2011) Welfare issues in horse racing. In: Mcllwraith C. W. and Rollin B. E., Eds. Equine Welfare. John Wiley \& Sons, Oxford, UK

Australian Racing Board (2014) Australian Racing Fact Book: A guide to the racing industry in Australia 2013-2014, 15th edn. Racing Information Services Australia

Barker D., Barker-Ruchti N., Rynne S., Lee J. (2014a) "Just do a little more": examining expertise in high performance sport from a sociocultural learning perspective. Reflect. Pract. 15, 92-105

Barker D., Barker-Ruchti N., Wals A., Tinning R. (2014b) High performance sport and sustainability: a contradiction of terms? Reflect. Pract. 15, 1-11

Barker-Ruchti N., Barker D., Annerstedt C. (2014) Techno-rational knowing and phronesis: the professional practice of one middledistance running coach. Reflect. Pract. 15, 53-65

Bartley P. (2015) Sport of kings - and cheats who dope - in crisis. The Age. http://www.theage.com.au/sport/horseracing/sport-ofkings-and-cheats-who-dope-in-crisis-20150710-gi8w35.html

Benns M. (2013) Fixed: Cheating, Doping, Rape and Murder... The Inside Track on Australia's Racing Industry. Random House Australia, North Sydney, NSW

Birke L., Hockenhull J. (2015) Journeys Together: Horses and Humans in Partnership. Soc. Anim. 23, 81-100 
Boden L. A., Anderson G. A., Charles J. A., Morgan K. L., Morton J. M., Parkin T. D. H., Slocombe R., F., Clarke A. F. (2006) Risk of fatality and causes of death of Thoroughbred horses associated with racing in Victoria, Australia: 1989-2004. Equine Vet. J. 38, 312-318

Bogdanich W., Drape J., Miles D. L., Palmer G. (2012) Death and Disarray at America's Racetracks. New York Times. http://www. nytimes.com/2012/03/25/us/death-and-disarray-at-americasracetracks.html

Broom D. M. (2011) A History of Animal Welfare Science. Acta Biotheor. 59, 121-137

Buller H., Morris C. (2008) Beasts of a different burden: Agricultural sustainability and farm animals. In: Fish R., Seymour S., Steven M. and Watkins C., Eds. Sustainable Farmland Management: Transdisciplinary Approaches, First edition. CABI, Wallingford, UK; Cambridge, MA, 135-148

Camporesi S., Knuckles J. A. (2014) Shifting the burden of proof in doping: lessons from environmental sustainability applied to highperformance sport. Reflect. Pract. 15, 106-118

Castañeda H., Kline N., Dickey N. (2010) Health Concerns of Migrant Backstretch Workers at Horse Racetracks. J. Health Care Poor Unders. 21, 489-503

Chenery S. (2013) They shoot horses, don't they? Sydney Morning Herald, http://www.smh.com.au/environment/animals/theyshoot-horses-dont-they-20130927-2u8nh

Coalition for Horse Racing Integrity (2015) Support the Thoroughbred Horse racing Anti-Doping Act of 2015. http://www.horseracingintegrity.com/legislationoverview.aspx.

Coalition for the Protection of Racehorses (2014) Deathwatch Report 2014. Melbourne

Costanza R., Alperovitz G., Daly H., Farley J., Franco C., Jackson T., Kubiszewski I., Schor J., Victor P. (2013) Building a Sustainable and Desirable Economy-in-Society-in-Nature. In: Starke L. (ed) State of the World 2013: Is Sustainability Still Possible? Island Press, Washington, 126-142

Direktorium für Vollblutzucht und Rennen (2013) Jahresbericht 2012. Köln

Dobson A. (1998) Justice and the Environment: Conceptions of Environmental Sustainability and Theories of Distributive Justice. Oxford University Press, USA

Duffy C. (2013) Racing's dark side, allegations of exploitation against some of the sport's biggest names. 7:30 Report. Australian Broadcasting Corporation

European Society for Agricultural and Food Ethics (2012) Climate Change and Sustainable Development: Ethical Perspectives on Land Use and Food Production. Wageningen Academic Pub, Wageningen, Netherlands

Garlick S., Austen R. (2014) Learning about the emotional lives of kangaroos, cognitive justice and environmental sustainability. Relat. Anthr. 2, 33-48

Goto M. (2013) The View from Japan. Presentation at the Fifty-Ninth Annual Round Table Conference on Matters Pertaining to Racing. Gideon Putnam Resort, Saratoga Springs, New York, 14 August

Gribben R. (2015) Horseracing industry faces race against time. http://www.telegraph.co.uk/finance/newsbysector/retailandconsumer/leisure/1 1627464/You-can-bet-on-changes-in-horseracing.html

Hitchens P. L., Blizzard C. L., Jones G., Day L. M., Fell J. (2009) The incidence of race-day jockey falls in Australia, 2002-2006. Med. J. Aust. 190, 83-86

Horn J. (2014) Has horse racing lost its way in a changing Australia? The Guardian. http://www.theguardian.com/sport/blog/2014/ oct/31/has-horse-racing-lost-its-way-in-a-changing-australia/print

Humane Society International, Brighter Green, World Society for the Protection of Animals (2013) Submission to SBSTA: Recommendations for Animal-Friendly and Sustainable Agriculture

International Federation of Horseracing Authorities (2014) http:// www.horseracingintfed.com/

Kavanagh B. (2013) The View from Europe. Presentation at the Fifty-Ninth Annual Round Table Conference on Matters Pertaining to Racing. Gideon Putnam Resort, Saratoga Springs, New York, 14 August
Keogh F. (2014) Godolphin doping scandal - one year on. BBC Sport. http://www.bbc.com/sport/0/horse-racing/27055292

Kidd C. V. (1992) The evolution of sustainability. J. Agric. Environ. Ethics 5, 1-26

Loland S. (2001) Record Sports: An Ecological Critique and a Reconstruction. J. Phil. Sport 28, 127-139

Loland S. (2006) Olympic Sport and the Ideal of Sustainable Development. J. Phil. Sport 33, 144-156

MacNeill J. (2006) The forgotten imperative of sustainable development. Environ. Policy Law 36, 167-170

Mann A. (2014) "Days are numbered" for jumps racing in South Australia. ABC News. http://www.abc.net.au/news/2014-05-22/ jumps- racing-days-are-numbered-in-south-australia/5471586

McManus P., Albrecht G., Graham R. (2013) The Global Horseracing Industry: Social, Economic, Environmental and Ethical Perspectives. Routledge, Abingdon UK

McManus P., Graham R., Ruse K. (2014) The construction of human-animal relations: National Jumps Day 2013 at Te Rapa, Hamilton, New Zealand. N. Z. Geogr. 70, 190-200

McManus P., Montoya D. (2012) Toward new understandings of human-animal relationships in sport: a study of Australian jumps racing. Soc. Cult. Geogr. 13, 399-420

Meyer H. (2015) Rigidity, elasticity and plasticity of the congenital dispositions of the horse. Pferdeheilkunde 31, 49-66

Miller J. (2014) How Kentucky Will Save Horse Racing From Itself. Daily Beast. http://www.thedailybeast.com/articles/2014/09/04/ how-kentucky-will-save-horse-racing-from-itself.html

Montoya D., McManus P., Albrecht G. (2012) Jumping to Conclusions? Media Coverage of Jumps Racing Debates in Australia. Soc. Anim. 20, 273-293

PETA (2014) Horse Racing Exposed: Drugs and Death. https://secure. peta.org/site/Advocacy? $\mathrm{cmd}=$ display\&page $=$ UserAction\&id $=$ 5345

Rockström J., Steffen W., Noone K., Persson A., Chapin F. S., Lambin E. F., Lenton T. M., Scheffer M., Folke C., Schellnhuber H. J., Nykvist B., de Wit C. A., Hughes T., van der Leeuw S., Rodhe H., Sörlin S., Snyder P. K., Costanza R., Svedin U., Falkenmark M., Karlberg L., Corell R. W., Fabry V. J., Hansen J., Walker B., Liverman D., Richardson K., Crutzen P., Foley J. A. (2009) A safe operating space for humanity. Nature 461, 472-475

Ross D. (2014) "Drugs and dead horses": US racing reels after Peta video broadside. The Guardian. http://www.theguardian.com/ sport/2014/aug/03/drugs-dead-horses-us-racing-peta-video

Schubring A., Thiel A. (2014) Growth problems in youth elite sports. Social conditions, athletes' experiences and sustainability consequences. Refl. Pract. 15, 78-91

Singer D., Lamb M. (2011) Driving sustainable growth for thoroughbred Racing and breeding: Findings and Recommendations. Presentation at the Fifty-Ninth Annual Round Table Conference on Matters Pertaining to Racing. Gideon Putnam Resort, Saratoga Springs, New York, 14 August

Steffen W., Persson A., Deutsch L., Zalasiewicz J., Williams M., Richardson K., Schellnhuber H. J., Turner II B. L., Wasson R. J. (2011) The Anthropocene: From global change to planetary stewardship. Ambio 40, 739-761

Steffen W., Sanderson A., Tyson P., Jäger J., Matson P., Moore III B,. Richardson K., Crumley C., Crutzen P., Folke C., Gordon L., Molina M., Ramanathan V., Rockström J., Scheffer M., Schellnhuber H. J., Svedin U. (2004) Global Change and the Earth System: A Planet Under Pressure - Executive Summary. Springer-Verlag, Berlin, Heidelberg, New York

Sterman J. D. (2012) Sustaining Sustainability: Creating a Systems Science in a Fragmented Academy and Polarized World. In: Weinstein M. P. and Turner R. E., Eds. Sustainability Science. Springer, New York, 21-58

von Keyserlingk M. A. G., Martin N. P., Kebreab E., Knowlton K. F., Grant R. J., Stephenson M., Sniffen C. J., Harner III J. P., Wright A. D., Smith S. I. (2013) Invited review: Sustainability of the US dairy industry. J. Dairy Sci. 96, 5405-5425

Warrington G., Dolan E., McGoldrick A., McEvoy J., MacManus C., Griffin M., Lyons D. (2009) Chronic weight control impacts on physiological function and bone health in elite jockeys. J. Sports. Sci. 27, 543-550 
Washington H. (2015) Demystifying sustainability: towards real solutions. Routledge, Abingdon, Oxon; New York, NY

Water Hay Oats Alliance (2014) Water Hay Oats Alliance. http://www.waterhayoatsalliance.com/

WCED (1987) Our Common Future. Oxford University Press, Oxford Weisbord B. (2014) TDN Shared Content. Thoroughbred Daily News. http://www.thoroughbreddailynews.com/shared_content. $\mathrm{cfm}$ ? id $=255$

Wuerthner G., Crist E., Butler T., Eds. (2014) Keeping the Wild: Against the Domestication of Earth. Island Press, Washington DC

\section{Erweiterte Zusammenfassung}

\section{Nachhaltigkeit, Vollblutrennen und die Notwendigkeit für Wandel}

Der McKinsey-Report, vom Jockey Club in den USA in Auftrag gegeben, hat bestätigt was Akteure in der Vollblutzucht und im Pferderennen schon erkennen mussten: Zucht und Rennen sind von rückgängigen Zahlen geprägt. Abgesehen von einigen Ausnahmen ist das Züchten und Rennen von Vollblütern auf globaler Ebene durch einem absteigenden Trend gekennzeichnet. Als eine der Hauptursachen für diese Entwicklung in den USA wurde im Report die öffentliche Wahrnehmung des Pferderennens genannt. Der Bericht hat ausdrücklich eine Verbindung zwischen den Bedenken der Öffentlichkeit in Sachen Tierschutz und dem Einsatz von verbotenen Substanzen einerseits und einem Rückgang von Wettumsatz und Besucherzahlen andererseits hergestellt. Die Autoren berichten, dass nur $22 \%$ der Öffentlichkeit einen positiven Eindruck vom Pferderennen hätten und dass $78 \%$ der Fans aufhören würden, auf Pferderennen zu wetten, wenn sie wüssten, dass Pferde nicht gut behandelt werden würden.

Insbesondere der Medikamentenmissbrauch, in den prominente Trainer und Rennställe in den letzten Jahren in verschiedenen Nationen verwickelt waren und einige noch sind, versetzt die Industrie in eine Grenzsituation. Parlamentarische Untersuchungen in mehreren Ländern, verdeckte Ermittlungen, journalistische Untersuchungen und Analysen sowie die Aufklärungs- und Informationsarbeit von Tierschutzorganisationen unterstütz† durch neve Informationstechnologien und Kommunikationsplatformen tragen zu einem veränderten Umfeld für das Rennbusiness bei. Die Pferderennindustrie hat bis vor nicht allzu langer Zeit noch ohne jede Rücksicht auf die Öffentlichkeit agieren können. Das ist nun nicht mehr möglich.

Innerhalb des Rennbusiness gibt es auch mehr und mehr Akteure, die insbesondere in Bezug auf die Integrität des Pferderennens Veränderungen fordern. Während die Reformvorschläge in Sachen Regulierung und Transparenz wichtige Maßnahmen beinhalten, besteht allerdings die Gefahr, dass sie das eigentliche Problem unberührt lassen: die Instrumentalisierung des Pferdes und die Konsequenzen, die sich daraus fürs Pferd und für das Image der Rennindustrie ergeben.

Der McKenzie-Bericht erklärt "nachhaltiges Wachstum" als das Ziel der Rennindustrie. Damit greifen die Autoren die Rhetorik der "nachhaltigen Entwicklung" auf, und verbinden sie mit dem Anliegen des Tierschutzes. Diese Verbindung wurde bereits im Bereich der nachhaltigen Landwirtschaft hergestellt. Es geht dabei um die sogenannte soziale Nachhaltig- keit, die besagt, dass die Behandlung von Tieren in der Landwirtschaft an den Wertvorstellungen der Öffentlichkeit gemessen werden muss. Die Diskrepanz zwischen Realität in der Pferderennindustrie einerseits und den veränderten gesellschaftlichen Normen andererseits kann in diesem Sinne als ein Nachhaltigkeitsproblem beschrieben werden kann.

Das Konzept der Nachhaltigkeit wird in dieser Studie als das Leitthema aufgegriffen. Aktuell wird davon ausgegangen, dass die Gesellschaft das Züchten, Trainieren und Rennen von Vollblütern vorerst weiterhin akzeptiert. Unter dieser Annahme wird das Konzept der Nachhaltigkeit als methodisches Instrument angewandt, um Fragen von Ethik und Schutz des Pferdes im Rennen zu beleuchten. Zu diesem Zweck wird zwischen dem Modell der "nachhaltigen Entwicklung" und dem Begriff der "Nachhaltigkeit" unterschieden. Im Allgemeinen basiert das Model der nachhaltigen Entwicklung auf der Idee des "nachhaltigen Wachstums". In anderen Untersuchungen wurde überzeugend nachgewiesen, dass unendliches Wachstum in einem begrenzten System eine Unmöglichkeit darstellt. Ein Konzept der Nachhaltigkeit, das auf ökologischen Grundsätzen beruht, stimmt mehr mit den Realitäten organischer Strukturen und Systeme überein. Die Grundlage der Idee der ökologischen Nachhaltigkeit besagt, dass sich die Pferde und die mit ihnen verbundenen Menschen in einem komplexen und verkoppelten sozio-ökologischen System befinden. Das Wohlergehen dieses Systems hängt von der physischen und emotionalen Integrität des Pferdes ab. In diesem Sinne wird in dieser Studie das Konzept der ökologischen Nachhaltigkeit als ein "Sprachsystem" eingesetzt. Sie beschreibt auch Beispiele aus dem Bereich der UmweltschutzGesetzgebung, die für das Pferderennen Anregungen liefern können. Das Hauptaugenmerk liegt aber auf dem Konzept des Wohlergehens im Zusammenhang mit dem sozio-ökologischen System. Daraus ergeben sich vier Themenbereiche, unter denen der Zusammenhang von Vollblutzucht und -rennen und Nachhaltigkeit untersucht werden: 1. Werte, Verpflichtungen und Rechte, 2. gemeinsames Wohlergehen, 3. Wettkampf und Nachhaltigkeit und 4. die Notwendigkeit der Erlangung never Erkenntnisse über die Erfahrungswelt des Pferdes. Diese werden im Folgenden erörtert.

Obwohl es in der Struktur, den Regelungen und Statistiken Unterschiede zwischen den verschiedenen Rennnationen gibt, so gibt es doch eine allgemeine zugrundeliegende Logik des Rennbusiness. Viele in der Rennndustrie bevorzugen es, von Diskussionen, die mit Werten zu tun haben, Abstand zu nehmen. Darin liegt ein gewisses Paradox, denn viele Praktiken offenbaren einen eindeutigen Wertestandpunkt. Dieser Wertestandpunkt besagt, dass es akzeptabel ist, dass Pferde sich Verletzungen durch Training und Rennen zuziehen oder tödlich verunglücken. Diese Werte besagen auch, dass das Pferd mittels der Verabreichung von Medikamenten oder verbotenen Substanzen und anderer Methoden mit dem Zweck der Leistungssteigerung angepasst werden kann. Zudem besagt dieses Wertesystem, dass gegenüber den Pferden, die den Anforderungen des Business nicht gewachsen sind, keine Verantwortung besteht, außer vielleicht die, ihnen einen "humanen" Tod zukommen zu lassen. Aufgrund der integrierten Untersuchung von Nachhaltigkeit und dem Nutzen des Pferdes in der Rennindustrie ergeben sich Parallelen zwischen der Ausbeutung unseres Planeten auf der einen, und der Ausbeutung der physischen Fähigkeit des Pferdes auf der anderen Seite. 
Im Gegensatz zu dem obigen Wertesystem besagt das Modell der ökologischen Nachhaltigkeit, dass Menschen Verpflichtungen dem Pferd gegenüber haben, insbesondere auch beruhend auf der Tatsache, dass das Pferd vom Moment seiner Zeugung bis zum Tode vollständig vom Menschen abhängig ist. Das Nachhaltigkeitsmodel besagt auch, dass Menschen verpflichtet sind, das Wohlergehen des Pferdes zu fördern. Die Wissenschaft, die sich mit dem Wohlergehen des Tieres beschäftigt, nimmt zunehmend Bezug auf positive Zustände im Bereich Wohlergehen. Das heißt, es wird nicht nur versucht, das Leiden zu beschreiben und einzuschränken, sondern es geht auch und vor allem darum, positive Zustände zu definieren und zu fördern. Freude, Zufriedenheit und Lebenserfüllung sind Konzepte, die zunehmend Einzug in die Diskussion um das Wohlergehen auch des Tieres finden. Wo das Wohlergehen kompromittiert wird, müssen die Bedingungen so verändert werden, dass es hergestellt werden kann. Das hat entsprechende Konsequenzen für Zucht, Haltung und Training.

Nachhaltigkeit besteht aus Bedingungen, die es ermöglichen, dass Mensch, Tier und Umwelt auf unbegrenzte Zeit in einem Zustand von gegenseitigem Wohlergehen, Sicherheit und Überleben bestehen können. Daraus ergibt sich die Frage, ob eine Gemeinschaft des gegenseitigen Wohlergehens zwischen Pferd und Mensch möglich ist, wenn die gemeinsamen Tätigkeiten maßgeblich vom Menschen vorgegeben werden. Aufgrund erster ethischer und ethologischer Untersuchungen kann das vorläufig bejaht werden. Es schließt sich dann die Frage an, ob das gegenseitige Wohlergehen auch unter Wettkampfbedingungen möglich ist. Studien im Zusammenhang von Hochleistungssport und Nachhaltigkeit berichten Ergebnisse, die Relevanz für das Pferderennen haben: Sie besagen, dass individuelle physische und emotionale Grenzen akzeptiert und berücksichtigt werden müssen. Fitness und Fähigkeit müssen als Konzept des soziokulturellen Lernens verstanden und entsprechend entwickelt werden. Fürsorge, Respekt, Achtung, Wertschätzung und Dialog mit dem Athleten sind die Basis der Beziehung. Und schließlich, Wettbewerbsfähigkeit und Mitgefühl sind Faktoren, die nebeneinander existieren können. Werden diese Erkenntnisse aufs Pferd übertragen, so kommt das Konzept der Autonomie des Tieres zur Geltung, was eine neve Betrachtungsweise des Pferd-Mensch-Verhältnisses mit sich.
Viele im Rennbusiness behaupten, das Pferd liebe es, im Wettkampf zu rennen und zu springen. Solche Behauptungen sind in Frage zu stellen. Es besteht die Notwendigkeit, die Erlebniswelt aus der Sicht des Pferdes zu erkunden. Wie empfindet das Pferd die Praktiken im Training und im Rennen? Inwieweit fördern sie möglicherweise das Wohlergehen des Pferdes? Was bedeuted Wohlergehen, Lebenserfüllung, Freude und Entfaltung für das Pferd? Die Veterinärmediziner stehen damit vor ganz neven Fragestellungen. Es geht dann nicht mehr nur darum zu erkunden, mit welchen Methoden und Mitteln das Pferd den Anforderungen der Rennindustrie standhalten kann. Es geht vielmehr darum zu untersuchen, wie die positive Entwicklung des Pferdes unter Berücksichtigung seiner individuellen Disposition gefördert werden kann, wo die Grenzen der Belastungsfähigkeit des individuellen Pferdes sind und wie seine physische und emotionale Integrität gewährleistet werden kann. Diese neven Fragestellungen erfordern eine interdisziplinäre Herangehensweise, die Verhaltensforscher, Veterinäre, Ethiker, Hippologen aus der Praxis, Tierschutzorganisationen und andere miteinbeziehen. Gemeinsam ist das Wissen um das Vollblutpferd und die Konsequenzen, die sich daraus für dessen Verwendung im Rennbusiness ergeben, zu erforschen. Neve Modelle des Erfolgs könnten entwickelt werden, die andere Faktoren als lediglich den Gewinn des Rennens einbeziehen.

Die Auseinandersetzung mit der Frage um die Nachhaltigkeit des Züchtens, Trainierens und Rennens des Vollblutes ist unvermeidlich. Der oben zusammengefasste Bereich von Fragen der Ethik und des Wohlergehens des Pferdes aus der Sicht der Nachhaltigkeit skizziert Themenbereiche, die Teil dieser Auseinandersetzung sind. Es kann nicht mehr als selbstverständlich hingenommen werden, wie bisher das Pferd unter Ausschluss gesellschaftlicher Werte in der Rennindustrie zu nutzen. Es kann davon ausgegangen werden, dass die normative Weiterentwicklung ein permanenter Prozess auf dem Weg zur Nachhaltigkeit werden wird. Die Beteiligten der Zucht- und Rennindustrie könnten davon profitieren, sich aktiv an diesem Prozess zu beteiligen.

Schlüsselwörter: Tierschutz / Nachhaltigkeit / nachhaltige Entwicklung / Systemtheorie / Pferderennen / Natürlichkeit / Pferdeverhalten / Tierautonomie 